\title{
PENGARUH PENGELUARAN PEMERINTAH BIDANG KESEHATAN DAN PENGELUARAN PEMERINTAH BIDANG PENDIDIKAN TERHADAP INDEKS PEMBANGUNAN MANUSIA (IPM) DI PROVINSI SUMATERA UTARA
}

\author{
Rosnani Siregar, Hamni Fadlilah Nasution, Siti Fatimah Tanjung \\ IAIN Padangsidimpuan \\ Jalan T. Rizal Nurdin Km. 4,5 Sihitang, Padangsidimpuan \\ Email:
}

\begin{abstract}
Abstrak,
Permasalahan dalam penelitian ini adanya fenomena peningkatan indeks pembangunan manusia di Provinsi Sumatera Utara meningkat 75,5 persen tetapi pengeluaran pemerintah bidang kesehatan menurun 297.944.000.000 rupiah dan pengeluaran pemerintah bidang pendidikan menurun 272.544.00o.0oo rupiah pada tahun 2013. Hal yang terjadi tidak sesuai dengan teori yang dikemukakan oleh Todaro dimana teori tersebut menyatakan apabila indeks pembangunan manusia (modal manusia) meningkat maka pengeluaran untuk kesehatan dan pendidikan juga akan meningkat. Rumusan masalah apakah terdapat pengaruh pengeluaran pemerintah bidang kesehatan dan pengeluaran pemerintah bidang pendidikan terhadap indeks pembangunan manusia di Provinsi Sumatera Utara secara parsial maupun simultan. Tujuan penelitian ini untuk mengetahui pengaruh pengeluaran pemerintah bidang kesehatan dan pengeluaran pemerintah bidang pendidikan terhadap indeks pembangunan manusia (IPM) di Provinsi Sumatera Utara secara parsial dan simultan. Penelitian ini merupakan penelitian kuantitatif. Sampel yang digunakan sebanyak 31 sampel, data diperoleh melalui situs www.bps.sumut.go.id. Pengujian dalam penelitian ini menggunakan bantuan program SPSS Versi 23. Hasil penelitian menunjukkan bahwa kontribusi pengeluaran pemerintah bidang kesehatan dan pengeluaran pemerintah bidang pendidikan sebesar $52 \%$ sedangkan 48 persen di pengaruhi oleh variabel lain yang tidak dimasukkan dalam model penelitian ini. Adapun model regresinya IPM $=\mathrm{a}+\mathrm{b} 1 \mathrm{BK}+\mathrm{b} 2 \mathrm{BP}$ atau $\mathrm{IPM}=24,336+0,025 \mathrm{BK}+0,001 \mathrm{BP}$.Variabel pengeluaran pemerintah bidang kesehatan berpengaruh secara parsial terhadap indeks pembangunan manusia, hal tersebut dapat dibuktikan dengan melihat nilai $t_{h}(2,020)>t_{t}(1,701)$ dimana $t_{h}(2,020)>t_{h} 1,701$ maka $\mathrm{H}_{01}$ ditolak dan $\mathrm{H}_{\mathrm{a}}$ diterima. Variabel pengeluaran pemerintah bidang pendidikan tidak berpengaruh secara parsial terhadap indeks pembangunan manusia, hal tersebut dapat dibuktikan dengan melihat nilai $t_{\text {hitung }}$ sebesar 0,096 dan $t_{\text {tabel }}$ sebesar 1,701 sehingga $-t_{t}(-$ $1,701)<t_{h}(0,096)<t_{t}(1,701)$ sehingga $\mathrm{H}_{02}$ diterima maka $\mathrm{Ha}_{2}$ ditolak. Variabel pengeluaran pemerintah bidang kesehatan dan pengeluaran pemerintah bidang pendidikan berpengaruh secara simultan terhadap indeks pembangunan manusia, hal tersebut dibuktikan karena $\mathrm{F}_{\text {hitung }}(15,168)>\mathrm{F}_{\text {tabel }}(3,340)$ maka $\mathrm{H}_{\mathrm{o} 3}$ ditolak dan $\mathrm{H}_{\mathrm{a} 3}$ diterima.
\end{abstract}

\section{Kata Kunci : Pengeluaran Pemerintah Bidang Kesehatan, Pengeluaran Pemerintah Bidang Pendidikan Dan Indeks Pembangunan Manusia.}

\section{Abstract,}

The problem in this study is that the phenomenon of an increase in the human development index in North Sumatra Province increased by 75.5 percent but the government expenditure 


\section{PENGARUH PENGELUARAN PEMERINTAH BIDANG KESEHATAN DAN PENGELUARAN PEMERINTAH BIDANG PENDIDIKAN TERHADAP INDEKS PEMBANGUNAN MANUSIA (IPM) DI PROVINSI SUMATERA

on health decreased 297,944,000,000 rupiah and government expenditure in education decreased by 272,544,000,000 rupiah in 2013. What happened was not in accordance with the theory which was put forward by Todaro where the theory states that if the human development index (human capital) increases, spending on health and education will also increase. The formulation of the problem is whether there is an influence of government spending on health and government expenditure on education on the human development index in North Sumatra Province partially or simultaneously. The purpose of this study was to determine the effect of government spending on health and government expenditure on education on the human development index (HDI) in North Sumatra Province partially and simultaneously. This research is quantitative research. The sample used was 31 samples, data obtained through the site www.bps.sumut.go.id. The test in this study used the SPSS Version 23. program. The results showed that the contribution of government expenditure on health and government expenditure in education was $52 \%$ while $48 \%$ was influenced by other variables not included in this research model. The regression model is HDI $=\mathrm{a}+\mathrm{b} 1 \mathrm{BK}+$ b2BP or HDI $=24,336+0,025 \mathrm{BK}+0,001 \mathrm{BP}$. Variables of government health expenditure have a partial effect on the human development index, this can be proved by looking at the value of th $(2,020)>t t(1,701)$ where th $(2,020)>$ th 1,701 then Ho1 is rejected and Ha1 is accepted. The variable government expenditure on education does not partially affect the human development index, it can be proved by looking at the value of $t$ count of 0.096 and $t$ table of 1.701 so $-\mathrm{tt}(-1.701)<\mathrm{th}(0.096)<\mathrm{tt}(1,701)$ so that Ho2 is accepted then Ha2 rejected. Variables of government expenditure on health and government expenditure in education have an effect simultaneously on the human development index, this is proven because Fcount $(15,168)>$ Ftable $(3,340)$ then Ho3 is rejected and Ha3 is accepted.

Keywords: Government Spending on Health, Government Expenditures in the Field of Education and Human Development Index

\section{PENDAHULUAN}

Indeks pembangunan manusia adalah suatu proses meningkatkan pilihan yang lebih

banyak lagi bagi manusia untuk hidup ataupun proses peningkatakan kemampuan manusia.

Proses tersebut dikonsentrasikan secara merata pada peningkatan formasi kemampuan manusia melalui investasi pada diri manusia dan pemanfaatan dari kemampuan manusia melalui penciptaan kerangka partisipasi untuk menghasilkan pendapatan dan peningkatan kesempatan kerja (Badan Pusat Statistik, 2014).

Indonesia mengalami krisis ekonomi yang terjadi pada tahun 1998 tetapi peningkatan indeks pembangunan manusia Sumatera Utara pada tahun tersebut mencapai 73,4 dan pada tahun berikutnya selalu mengalami ketidakseimbangan untuk pencapaian indeks pembangunan manusia, hingga tahun 2009 indeks pembangunan manusia mengalami 
peningkatan sebesar 73,8 persen dan pada tahun berikutnya mulai mengalami peningkatan. Indeks pembangunan manusia Provinsi Sumatera Utaraberada pada capaian status sedang dan status tinggi, dapat dilihat pada tabel I.1 dibawah ini.

Tabel I.1

Indeks Pembangunan Manusia Sumatera Utara

\begin{tabular}{|c|c|c|}
\hline Tahun & IPM Sumatera Utara $(\boldsymbol{\%})$ & Status IPM \\
\hline 2011 & 74,6 & Tinggi \\
\hline 2012 & 75,1 & Tinggi \\
\hline 2013 & 75,5 & Tinggi \\
\hline 2014 & 68,9 & Sedang \\
\hline 2015 & 69,5 & Sedang \\
\hline 2016 & 70,0 & Tinggi \\
\hline
\end{tabular}

Sumber : BPS Sumatera Utara Data Diolah

Peningkatan indeks pembangunan manusia di Provinsi Sumatera Utara yaitu selisih peningkatan antara tahun 2011-2012 sebesar 0,5 persen, pada tahun 2012-2013 terjadi peningkatan yaitu 0,4 persen, pada tahun 2013-2014 mengalami penurunan sebesar 6,6 persen, selanjutnya pada tahun 2014-2015 mengalami penurunan yaitu 0,4 persen, dan pada tahun 2015-2016 mengalami peningkatan lagi sebesar 1,5 persen. Jadi dapat disimpulkan bahwa peningkatan yang terjadi pada indeks pembangunan manusia di Provinsi Sumatera Utara mengalami ketidakseimbangan antara tahun yang satu dengan tahun berikutnya.

Menurut Todaro modal manusia (Human Capital) memiliki indikator diantaranya adalah pendidikan dan kesehatan yang merupakan tujuan pembangunan yang mendasar, keterkaitan antara kesehatan dan pendidikan mencakup perlakuan analitis yang serupa, karena keduanya merupakan bentuk dari modal manusia dampak ganda dari pengeluaran untuk kesehatan terhadap efektivitas sistem pendidikan. Jika modal manusia meningkat maka pengeluaran untuk kesehatan dan pendidikan juga meningkat (Michael P. Todaro, 2003).

Pengeluaran pemerintah bidang kesehatan dapat dilihat pada tabel I.3 dibawah ini: 
PENGARUH PENGELUARAN PEMERINTAH BIDANG KESEHATAN DAN PENGELUARAN PEMERINTAH BIDANG PENDIDIKAN TERHADAP INDEKS PEMBANGUNAN MANUSIA (IPM) DI PROVINSI SUMATERA

UTARA

Tabel I.2

Pengeluaran Pemerintah Bidang Kesehatan Provinsi Sumatera Utara

\begin{tabular}{|c|c|c|}
\hline Tahun & $\begin{array}{c}\text { Pengeluaran Pemerintah } \\
\text { Sektor Kesehatan }\end{array}$ & $\begin{array}{c}\text { Laju Pertumbuhan } \\
\text { Pengeluaran Pemerintah } \\
\text { Bidang Kesehatan (\%) }\end{array}$ \\
\hline 2011 & 93.814 .902 .000 & - \\
\hline 2012 & 183.385 .090 .750 & 95,4 \\
\hline 2013 & 297.944 .000 .000 & 61,5 \\
\hline 2014 & 401.700 .368 .532 & 74,1 \\
\hline 2015 & 532.876 .000 .000 & 75,3 \\
\hline 2016 & 513.093 .000 .000 & 94,6 \\
\hline
\end{tabular}

Sumber : BPS Sumatera Utara Data Diolah

Berdasarkan Tabel I.2 pengeluaran pemerintah bidang kesehatan Provinsi Sumatera Utara pada tahun 2011 sebesar 93.814.902.000 rupiah dengan memiliki selisih dengan tahun 2012 sebesar 95,4 persen, pada tahun 2013 sebesar 297.944.000.000 rupiah dan selisih antara tahun 2012-2013 yaitu 61,5 persen, pada tahun 2014 mengalami peningkatan sebesar 401.700.368.532 rupiah dengan selisih antara tahun 2013-2014 yaitu 74,1 persen, pada tahun 2015 meningkat kembali sebesar 532.876.000.000 rupiah dengan selisih antara tahun 20142015 sebesar 75,3 persen, dan pada tahun 2016 peningkatan terjadi sangat pesat yaitu sebesar 513.093.000.000 rupiah dengan selisih antara tahun 2015-2016 sebesar 94,6 persen. Disimpulkan bahwa pengeluaran pemerintah untuk bidang kesehatan sangat tinggi dan selalu mengalami peningkatan setiap tahunnya.

Pengeluaran pemerintah bidang pendidikan dapat dilihat pada tabel I.3 dibawah ini. 
Tabel I.3

Pengeluaran Pemerintah Bidang Pendidikan Provinsi Sumatera Utara

\begin{tabular}{|c|c|c|}
\hline Tahun & $\begin{array}{c}\text { Pengeluaran Pemerintah } \\
\text { Sektor Pendidikan }\end{array}$ & $\begin{array}{c}\text { Laju Pertumbuhan } \\
\text { Pengeluaran } \\
\text { Pemerintah Bidang } \\
\text { Pendidikan (\%) }\end{array}$ \\
\hline 2011 & 241.686 .770 .575 & - \\
\hline 2012 & 335.131 .225 .580 & 38,6 \\
\hline 2013 & 272.544 .000 .000 & $-18,6$ \\
\hline 2014 & 329.608 .956 .818 & 20,9 \\
\hline 2015 & 107.138 .300 .000 & $-67,4$ \\
\hline 2016 & 216.895 .200 .000 & 41,7 \\
\hline
\end{tabular}

Sumber : BPS Sumatera Utara Data Diolah

Berdasarkan Tabel I.4 diataspengeluaran pemerintah bidang pendidikan Provinsi Sumatera Utara pada tahun 2011 mencapai 241.686.770.575 rupiah dengan selisih antara tahun 2011-2012 sebesar 38,6 persen kemudian pada tahun 2013 mencapai 272.544.000.000 rupiah dan selisih antara tahun 2012-2013 mengalami penurunan sebesar -18,6 sedangkan pada tahun 2014 pencapaian sebesar 329.608.956.818 rupiah dan selisih tahun 2013-2014 meningkat sebesar 20,9 persen, pada tahun 2015 pengeluaran menurun yaitu 107.138.300.000 rupiah dan selisihnya menurun drastis sebesar $-67,4$ persen dan pada tahun 2016 pengeluaran meningkat sebesar 256.895.200.000 rupiah dengan selisih 41,7 persen peningkatan yang sangat signifikan dibandingkan dengan tahun sebelumnya. Jadi dapat disimpulkan bahwa pengeluaran pemerintah bidang pendidikan mengalami penurunan pada tahun 2013 dan 2015 dan meningkat secara signifikan pada tahun 2016.

Berdasarkan latar belakang serta beberapa fenomena di atas dimana peningkatan indeks pembangunan manusia di Provinsi Sumatera Utara meningkat 75,5 persen tetapi pengeluaran pemerintah bidang kesehatan menurun 297.944.000.000 rupiah dan pengeluaran pemerintah bidang pendidikan menurun 272.544.000.000 rupiah pada tahun 2013. Sehingga peneliti tertarik untuk melakukan penelitian berjudul"Pengaruh Pengeluaran Pemerintah 
PENGARUH PENGELUARAN PEMERINTAH BIDANG KESEHATAN DAN PENGELUARAN PEMERINTAH BIDANG PENDIDIKAN TERHADAP INDEKS PEMBANGUNAN MANUSIA (IPM) DI PROVINSI SUMATERA

UTARA

Bidang Kesehatan Dan Pengeluaran Pemerintah Bidang Pendidikan Terhadap Indeks Pembangunan Manusia Di Provinsi Sumatera Utara".

\section{TINJAUAN TEORITIK}

\section{Indeks Pembangunan Manusia (IPM)}

UNDP (United Nation Development Progamme), mendefenisikan pembangunan manusia sebagai suatu proses untuk memperluas pilihan-pilihan bagi penduduk. Dalam konsep tersebut penduduk ditempatkan sebagai tujuan akhir (the ultimate end) sedangkan upaya pembangunan dipandang sebagai sarana (principal means ) untuk mencapai tujuan itu (Nurul Izzah, 2015). Islam menempatkan manusia sebagai fokus dalam pembangunan. Pemikiran pembangunan menurut paradigma Islam diantaranya berasal dari Ibnu Khaldun dan Shah Wali Allah dua tokoh Islam yang didup pada periode waktu yang berbeda. Islam menunjukkan jalan hidup yang menyeluruh bagi ummat manusia yang tidak membedakan manusia menurut ras, kebangsaan, atau warna kulit. Manusia dilihat hanya dari pengakuan manusia pada keesaan Tuhan da keputusan manusia pada kehendak dan bimbingan-Nya.

Misi manusia menjadi pengabdi bagi penciptanya sementara ibadah dan pengabdian pada Sang Pencipta menjadi tujuan hidup manusia. Karena Islam bersifat menyeluruh (kaffah), ibadah juga bersifat menyeluruh. Ibadah mencakup aspek spiritual maupun material sepanjang sesuai dengan bimbingan Tuhan dalam mencapai keadilan bagi semua makhluk. Oleh karena itu, agar proses pembangunan dapat dipandang sebagai ibadah, pembangunan harus dilaksanakan berdasarkan petunjuk dari Tuhan Yang Maha Esa. Hal tersebut menunjukkan bahwa pembangunan spiritual dan material seharusnya tidak dipisahkan, tetapi dibangun secara bersama.

Titik berat pendekatan Islam pada pembangunan spiritual, moral, dan etika yang mengindikasikan derajat perhatian yang tinggi yang telah melekat dalam proses pembangunan 
Islam. Dengan kata lain, jika konsep pembangunan seseorang tidak sesuai, semua yang terbentuk sebagai hasil konsep tersebut juga tidak akan sesuai. Hal ini menejalaskan bahwa jika manusia sebagai agen pembangunan tidak menanamkan dan menjalankan nilai moral dan etika universal, tidak ada jaminan bahwa dia akan merasa bertanggung jawab baik kepada Tuhan maupun masyarakat dalam upayanya mencapai tujuan-tujuan pembangunan. Oleh karena itu, manusia masih akan mudah terjerat pada bahaya korupsi, ketidakjujuran, kurangnya komitmen, praktisi bisnis yang tidak etis dan lain-lain yang serupa dengan hal itu.

Pembangunan dalam kerangka Islam ditentukan pada pola nilai (value pattern) yang melekat dalam Alquran dan Sunnah kedua sumber tersebut membentuk kerangka rujukan yang menjadi dasar dalam upaya pembangunan sehingga menjadi titik awal dalam perumusan kebijakan pembangunan, tujuan dan proses pemuatan keputusan pada semua level (Mudrajat Kuncoro, 2004). Tujuan pembangunan dalam perspektif Islam adalah terciptanya kesuksesan di akhirat, sukses adalah apabila kita selamat dari neraka dan masuk kedalam surga. Inilah yang disebut dengan kebahagiaan hakiki. Dalam al- Qur'an orang-orang yang sukses disebut sebagai orang-orang yang akan mewarisi Surga Firdaus.

Allah berfirman dalam $Q S . A l-M u$ 'minunayat 11.

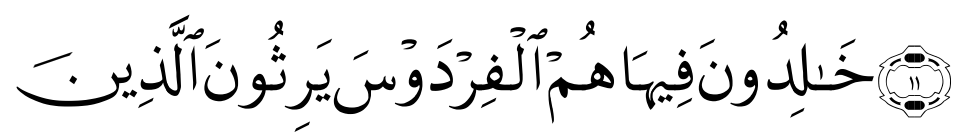

Artinya: Mereka itulah orang-orang yang akan mewarisi. (yakni) yang akan mewarisi surga Firdaus. Mereka kekal di dalamnya (QS. Al-Mu'minun: 11) (Departemen Agama RI, 2011).

Berdasarkan Ayat diatas menjelaskan bahwa tujuan pembangunan dalam perspektif Islam adalah tercapainya kesuksesan di akhirat. Sayyid Qathub memaparkan ayat ini merupakan ayat penutup sifat- sifat terpuji bagi seorang mukmin yang pandangannya masing- 


\section{PENGARUH PENGELUARAN PEMERINTAH BIDANG KESEHATAN DAN PENGELUARAN PEMERINTAH BIDANG PENDIDIKAN TERHADAP INDEKS PEMBANGUNAN MANUSIA (IPM) DI PROVINSI SUMATERA

masing dapat meraih kebijakan dengan kesempurnaan iman dan budi pekerti seorang tercermin dari ayat di atas (M. Quraish Shihab, 2002).

Dalam perspektif Islam, pembangunan dilaksanakan berdasarkan lima pondasi filososfis, yaitu (Mudrajad Kuncoro, 2010): pertama, Tauheed Uluhiyah, yaitu percaya pada Kemahatunggalan Tuhan dan semua yang di alam semesta merupakan kepunyaan-Nya. Dalam konteks upaya pembangunan, manusia harus sadar bahwa semua sumber daya yang tersedia adalah kepunyaan-Nya sehingga tidak boleh hanya dimanfaatkan untuk pemenuhan kepentingan pribadi. Kedua, Tauheed Rububiyyah, yaitu percaya bahwa Tuhan sendirilah yang menentukan keberlanjutan dan hidup dari ciptaannya serta menuntun siapa saja yang percaya kepada-Nya kepada kesuksesan. Dalam konteks pembangunan, manusia harus sadar bahwa pencapaian tujuan-tujuan pembangunan tidak hanya bergantung pada upaya sendiri, tetapi juga pada pertolongan Tuhan, baik yang terlihat maupun tidak terlihat. Ketiga, Khilafah, yaitu peranan manusia sebagai wakil Tuhan di bumi. Disamping sebagai wakil atas segala sumber daya yang diamanatkan kepadanya, manusia yang beriman juga harus menjalankan tanggung jawabnya sebagai pemberi teladan atau contoh yang baik bagi manusia lainnya. Keempat, Tazkiyah an-nas, ini merujuk kepada pertumbuhan dan penyucian manusia sebagai prasyarat yang diperlukan sebelum manusia menjalankan tanggung jawab yang ditugaskan kepadanya. Manusia adalah agen pembangunan dan perubahan. Oleh karena itu pembangunan dan perubahan apa pun yang terjadi sebagai akibat upaya manusia ditunjukkan bagi kebaikan orang lain dan tidak hanya bagi pemenuhan kepentingan pribadi. Kelima, Alfalah, yaitu konsep keberhasilan dalam Islam bahwa keberhasilan apa pun yang dicapai di kehidupan dunia akan mempengaruhi keberhasilan di akhirat sepanjang keberhasilan yang dicapai semasa hidup di dunia tidak menyalahi petunjuk atau bimbingan yang telah Tuhan 
tetapkan. Upaya-upaya bagi pembangunan di dunia ataupun persiapan bagi kehidupan di akhirat.

\section{Pengeluaran Pemerintah Bidang Kesehatan}

Kesehatan merupakan inti dari kesejahteraan baik secara fisik, mental dan sosial. Kesehatan merupakan faktor penting atas kehadiran anak disekolah. Pelayanan publik untuk kesehatan adalah sebagai upaya pemenuhan kebutuhan publik dan pelaksanaan ketentuan peraturan perundang- undangan. Dalam hal ini yang dimaksud dengan penyelenggaraan pelayanan publik adalah instansi pemerintah daerah, baik pemerintah pusat maupun pemerintah daerah. Kesehatan merupakan salah satu kebutuhan dasar masyarakat, oleh karena itu kesehatan adalah hak bagi setiap warga masyarakat yang dilindungi Undang-Undang Dasar. Perbaikan pelayanan kesehatan pada dasarnya merupakan suatu investasi sumber daya manusia untuk mencapai masyarakat yang sejahtera (welfare society). Tingkat kesehatan masyarakat akan sangat berpengaruh terhadap tingkat kesejahteraan masyarakat, karena tingkat kesehatan memiliki keterkaitan yang erat dengan kemiskinan. Sementara itu, tingkat kemisikinan akan terkait dengan tingkat kesejahteraan (Adi Widodo dkk, 2011).

Dalam sejarah terdapat beberapa nama Muslimin yang dikenal yaitu Atir bin Amr bin Hani As-Sakuni, ahli yang satu ini diminta untuk mengobati khalifah ketika terluka dalam suatu peperangan.Selama masa kepemimpinan Rasulullah dan Khalifah, para ulama, ahli kedokteran dan orang-orang yang dapat menulis penghargaaan dan dimanfaatkan untuk penyebaran ilmu pengetahuan. Para ahli kesehatan pada pemerintahan Ali juga ada yang beragama Kristen dan Zoroaster, kenyataannya bagaimana mereka diminta untuk mengobati dan menyelamatkan hidup khalifah menjadi bukti kedekatan hubungan yang saling percaya dan menghargai (Adiwarman Azwar Karim, 2012). 


\section{PENGARUH PENGELUARAN PEMERINTAH BIDANG KESEHATAN DAN PENGELUARAN PEMERINTAH BIDANG PENDIDIKAN TERHADAP INDEKS PEMBANGUNAN MANUSIA (IPM) DI PROVINSI SUMATERA

\section{Pengeluaran Pemerintah Bidang Pendidikan}

Sama halnya dengan kesehatan, pendidikan merupakan suatu bentuk investasi sumber daya manusia. Pendidikan merupakan salah satu komponen utama dalam kebutuhan masyarakat, dan cara mengatasi pendidikan yang rendah adalah dengan melalui perbaikan kualitas pendidikan. Pelayanan pendidikan masyarakat yang paling elementer adalah pendidikan dasar, yang oleh pemerintah diterjemahkan dalam program wajib belajar sembilan tahun.Pemerintah hendak menjamin bahwa semua anak dapat bersekolah, sehingga diperlukan alokasi aggaran pendidikan yang besar. Dalam pemenuhan anggaran tersebut amanat amandemen UUD 1945 telah mensyaratkan alokasi anggaran pendidikan minimal sebesar 20 persen dari total anggaran pemerintah. Peran pendidikan dalam pengelolaan sumber daya manusia yang produktif seperti menghasilkan tenaga-tenaga manusia terampil.Jika dikaitkan dengan tuntutan global maka pendidikan harus dipandang sebagai upaya mempersiapkan ilmu pengetahuan yang dapat mengoptimalkan segenap potensi yang dimilikinya (Rusli Yusuf, 2011).

Dalam UU-RI No. 2 Tahun 1989 disebutkan bahwa tujuan pendidikan nasional adalah mencerdaskan kehidupan bangsa dan mengembangkan manusia Indonesia seutuhnya, yaitu manusia yang beriman dan bertakwa terhadap Tuhan yang Maha Esa dan berbudi pekerti luhur, memiliki pengetahuan dan keterampilan, kesehatan jasmani dan rohani, kepribadian yang mantap, dan mandiri serta rasa tanggung jawab kemasyarakatan dan kebangsaan (Sudarwan Danim, 2003). Mengembangkan institusi pendidikan dari tingkat sekolah, pra universitas, diploma hingga tingkat universitas perlu dilakukan.Telah ditekankan bahwa pendidikan merupakan syarat yang tak terpisahkan untuk mewujudkan pertumbuhan ekonomi 
Al-Masharif: Jurnal Ilmu Ekonomi dan Keislaman

Volume 6 Nomor 1 Ed. Januari-Juni 2018 : hal. 82-105

p-ISSN: 2356-4628 e-ISSN : 2579-8650

yang lebih pesat.Maka, dalam usaha mempercepat pembangunan ekonomi, program mengambangkan sistem dan institusi pendidikan perlu dijalankan (Sadono Sukirno, 2006).

Tujuan pendidikan yang terkandung pada distribusi pendapatan dalam perspektif ekonomi Islam adalah pendidikan akhlak al-karimah seperti suka memberi, berderma, dan mengutamakan orang lain, serta mencusikan diri dari akhlak al-mujammil, seperti pelit, laba, dan mementingkan diri sendiri (Rozalinda, 2011). Kualitas manusia dapat dilihat terutama dari maju tidaknya pendidikan dan kesehatan serta bidang sosial dan kebudayaan, pendidikan (baik formal maupun nonformal) dan kesehatan mencerminkan dan mempengaruhi produktivitas.Hal ini berarti bahwa orang yang mungkin bekerja keras, tetapi tidak mencapai hasil produksi yang banyak, dan dengan demikian juga tidak akan memperoleh pendapatan yang layak. Juga akan kurang terbuka untuk kemajuan zaman dengan penggunaan teknologi modern (T. Gilarso, 2004). Menurut Muhammad Fadlil al-Jamali, pendidikan Islam upaya mengembangkan, mendorong, serta mengajak manusia untuk lebih maju dan berlandaskan nilai-nilai unggul yang tinggi dan kehidupan yang mulia, sehingga terbentuk pribadi yang sempurna baik yang berkaitan dengan akal, perasaan, maupun perbuatan (Mujtahid, 2011).

Kata pengetahuan ('ilm) merupakan kata yang sering kita dengar, hanya dengan menjadi manusia yang memiliki ilmu pengetahuan manusia bisa mengklaim suprioritas atas makhluk-makhluk Tuhan yang lain. Hal ini karena pengetaahuan merupakan alat untuk mencapai keselamatan spiritual secara bersama-sama. Karena itu islam membedakan dengan jelas antara yang bodoh dan yang berpengetahuan dalam Al-Quran surah Al-An'am ayat 37:

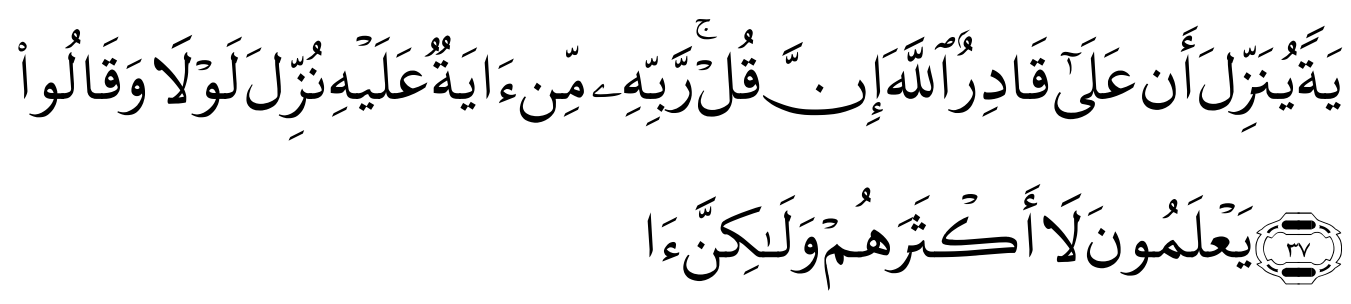




\section{PENGARUH PENGELUARAN PEMERINTAH BIDANG KESEHATAN DAN PENGELUARAN PEMERINTAH BIDANG PENDIDIKAN TERHADAP INDEKS PEMBANGUNAN MANUSIA (IPM) DI PROVINSI SUMATERA \\ UTARA}

Artinya: Dan mereka (orang-orang musyrik Mekah) berkata: "Mengapa tidak diturunkan kepadanya (Muhammad) suatu mukjizat dari Tuhannya?" Katakanlah: Sesungguhnya Allah Kuasa menurunkan suatu mukjizat, tetapi kebanyakan mereka tidak mengetahui.

Dalam ayat ini memberitahukan bahwa ihwal kaum musyrikin, mengapa tidak menurunkan kepadanya suatu mukjizat dari Tuhan yakni keluarbiasaan menurut persoalan yang mereka kehendak untuk mereka ketahui (Muhammad Nasib, 1999). Ayat tersebut menganjurkan kita untuk semangat dalam mencari ilmu. Selain itu ayat Al-Quran yang menjelaskan tentang mencari ilmu terdapat pada surah An-Nahl ayat 78:

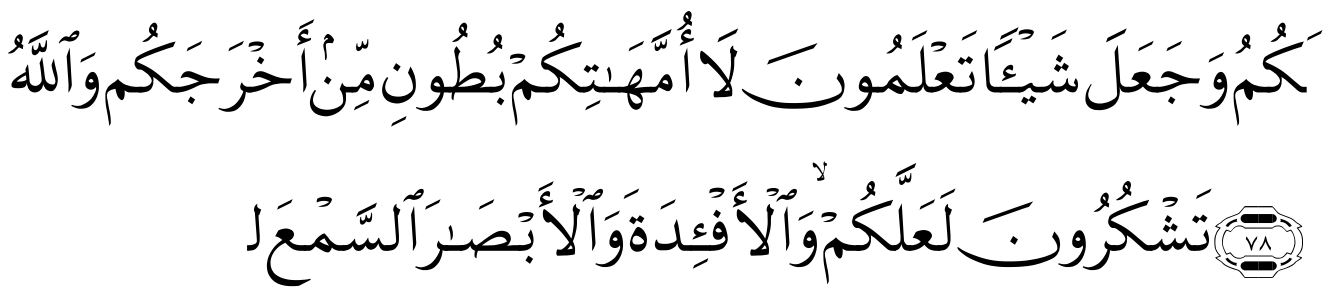

Artinya : Dan Allah mengeluarkan kamu dari perut ibumu dalam Keadaan tidak mengetahui sesuatupun, dan Dia memberi kamu pendengaran, penglihatan dan hati, agar kamu bersyukur (Departemen Agama RI, 2010).

Berdasarkan ayat diatas tentang nikmat Allah kepada manusia, dalam ayat tersebut Allah memberikan bekal kepada manusia untuk melaksanakan amanah yang mereka emban, dan bekal itu adalah pendengaran, penglihatan, dan hati nurani.

\section{Hipotesis}

Hipotesis adalah jawaban sementara terhadap masalah penelitian yang secara teoritis dianggap paling mungkin atau paling tinggi Secara teknik, hipotesis adalah pernyataan mengenai keadaan populasi yang akan diuji kebenarannya melalui data yang diperoleh dari sampel penelitian (S. Margono, 2000). Berdasarkan uraian diatas, maka dapat dirumuskan hipotesis penelitian sebagai berikut: 
$\mathrm{H}_{01}=\quad$ Tidak terdapat pengaruhpengeluaran pemerintah bidang kesehatan secara parsial terhadap indeks pembangunan manusia di Provinsi Sumatera Utara.

$\mathrm{H}_{\mathrm{a} 1}=$ Terdapat pengaruh pengeluaran pemerintah bidang kesehatan secara parsial terhadap indeks pembangunan manusiadi Provinsi Sumatera Utara.

$\mathrm{H}_{02}=\quad$ Tidak terdapat pengaruh pengeluaran pemerintah bidang pendidikan secara parsial terhadap indeks pembangunan manusia di Provinsi Sumatera Utara.

$\mathrm{H}_{\mathrm{a} 2}=$ Terdapat pengaruh pengeluaran pemerintah bidang pendidikan secara parsial terhadap indeks pembangunan manusia di Provinsi Sumatera Utara.

$\mathrm{H}_{03}=$ Tidak terdapat pengaruh pengeluaran pemerintah bidang kesehatan dan pengeluaran pemerintah bidang pendidikan terhadap indeks pembangunan manusia di Provinsi Sumatera Utarasecara simultan.

$\mathrm{H}_{\mathrm{a} 3}=$ Terdapat pengaruh pengeluaran pemerintah bidang kesehatan dan pengeluaran pemerintah bidang pendidikan terhadap indeks pembangunan manusia di Provinsi Sumatera Utarasecara simultan.

\section{METODE PENELITIAN}

Analisis data yang digunakan dalam penelitian ini agar sesuai dengan tujuan penelitian, guna mengetahui pengaruh pengeluaran pemerintah bidang kesehatan dan pengeluaran pemerintah bidang pendidikan terhadap indeks pembangunan manusia yaitu dengan menggunakan rumus regresi linier berganda. Persamaan regresi linier berganda yang digunakan dalam penelitian ini adalah :

$$
\mathrm{Y}=\alpha+\mathrm{b}_{1} \mathrm{X}_{1}+\mathrm{b}_{2} \mathrm{X}_{2}+\mathrm{e}
$$

$$
\begin{aligned}
& \text { Keterangan: } \\
& \mathrm{Y}=\text { Indeks Pembangunan Manusia (IPM) } \\
& \alpha=\text { Konstanta } \\
& \mathrm{b}_{1}=\text { KoefisienuntukvariabelPengeluaranPemerintahBidangKesehatan } \\
& \mathrm{b}_{2}=\text { KoefisienuntukvariabelPengeluaranPemerintahBidangPendidikan } \\
& \mathrm{E}=\text { Error } \\
& \mathrm{X}_{1}=\text { PengeluaranPemerintahBidangKesehatan }(\mathrm{BK})
\end{aligned}
$$




\section{PENGARUH PENGELUARAN PEMERINTAH BIDANG KESEHATAN DAN PENGELUARAN PEMERINTAH BIDANG PENDIDIKAN TERHADAP INDEKS PEMBANGUNAN MANUSIA (IPM) DI PROVINSI SUMATERA

$\mathrm{X}_{2}=$ PengeluaranPemerintahBidangPendidikan $(\mathrm{BP})$

Sehinggapengujiandalampenelitianiniadalah :

$\mathrm{IPM}=\alpha+\mathrm{b}_{1} \mathrm{BK}+\mathrm{b}_{2} \mathrm{BP}+\mathrm{e}$

\section{Pengujian Asumsi Klasik}

Uji asumsi klasik digunakan untuk menguji normalitas data penelitian, uji multikulinearitas, uji heteroskedastisitas dan uji autokorelasi. Menurut (Sugiono dan Susanto, 2015), uji normalitas bertujuan untuk menguji data penelitian baik variabel dependen maupun variabel independen terdistribusi normal atau tidak dengan menggunakan kolmogrov-smirnow pada taraf signifikan 0,05. Dan uji multikolinieritas digunakan untuk melihat adanya hubungan linier sempurna diantara variabel independennya dengan melihat nilai VIF (Variance Inflasion Factor). Dan uji heteroskedastisitas digunakan untuk mengetahui ada atau tidaknya penyimpangan asumsi klasik melalui penyebaran titik yang tidak membentuk pola.

\section{Pengujian Hipotesis}

Uji hipotesis digunakan untuk mengukur besarnya pengaruh variabel independen terhadap variabel dependen. Untuk mengukur seberapa jauh kemampuan model dalam menerangkan variasi dependen digunakan uji koefisien determinasi $\left(\mathrm{R}^{2}\right)$, menurut (Setiawan dan Kusrini, 2010), nilai yang mendekati satu berarti variabel-variabel independen memberikan hampir semua informasi yang dibutuhkan untuk memprediksi variasi variabel dependen. Untuk mengetahui apakah ada model regresi variabel independen secara parsial berpengaruh signifikan terhadap variabel dependen, maka digunakanlah uji $t$, menurut (Siregar, 2014), kaidah pengujian untuk menguji secara parsial yaitu jika $\mathrm{T}_{\text {hitung }} \leq \mathrm{T}_{\text {tabel }}$ maka $\mathrm{H}_{\mathrm{o}}$ diterima dan $\mathrm{H}_{\mathrm{a}}$ ditolak, dan jika $\mathrm{T}_{\text {hitung }} \geq \mathrm{T}_{\text {tabel }}$ maka $\mathrm{H}_{\mathrm{o}}$ ditolak dan $\mathrm{H}_{\mathrm{a}}$ diterima. Dan untuk mengetahui pengaruh semua variabel independen terhadap variabel dependen maka digunakanlah uji $\mathrm{F}$, uji ini dilakukan dengan syarat bila $\mathrm{F}_{\text {hitung }}<\mathrm{F}_{\text {tabel }}$ maka $\mathrm{H}_{\mathrm{o}}$ diterima dan $\mathrm{H}_{\mathrm{a}}$ ditolak, bila $\mathrm{F}_{\text {hitung }}>\mathrm{F}_{\text {tabel }}$ maka $\mathrm{H}_{\mathrm{o}}$ ditolak dan $\mathrm{H}_{\mathrm{a}}$ diterima.

\section{HASIL DAN PEMBAHASAN}

Didalam penelitian ini dikumpulkan data primer untuk mengetahui sejauh mana pengaruh pengeluaran pemerintah bidang kesehatan $\left(\mathrm{x}_{1}\right)$ dan pengeluaran pemerintah bidang pendidikan $\left(\mathrm{X}_{2}\right)$ terhadap indeks pembangunan manusia. Sebelum melakukan analisis data, terlebih dahulu uji normalitas dari data penelitian, adapun hasil uji normalitas penelitian ini adalah : 
Tabel 1

Hasil Uji Normalitas

\begin{tabular}{|ll|r|}
\hline & & \multicolumn{2}{|c|}{$\begin{array}{c}\text { Unstandardized } \\
\text { Residual }\end{array}$} \\
\hline $\mathrm{N}$ & & 31 \\
Normal Parameters & Mean &, 0000000 \\
& Std. Deviation & 3,57921084 \\
Most Extreme & Absolute &, 133 \\
Differences & Positive &, 078 \\
& Negative &,- 133 \\
Test Statistic & &, 133 \\
Asymp. Sig. (2-tailed) &, $170^{c}$ \\
\hline
\end{tabular}

a. Test distribution is Normal.

b. Calculated from data.

c. Lilliefors Significance Correction.

Berdasarkan tabel diatas dapat dilihat bahwa nilai Asymp . Sig (2-tailed) adalah 0,170, sehingga lebih besar dari nilai signifikan 0,05 $(0,170>0,05)$. Maka dapat disimpulkan bahwa nilai data tersebut memenuhi syarat untuk uji parametrik karena berdistribusi normal. Jika data sudah normal maka berikutnya adalah menguji multikolinieritas, adapun hasil ujinya adalah :

Tabel 2 Hasil Uji Multikolinearitas

\begin{tabular}{|c|c|c|c|c|c|c|c|}
\hline \multirow[b]{2}{*}{ Model } & \multicolumn{2}{|c|}{$\begin{array}{c}\text { Unstandardized } \\
\text { Coefficients }\end{array}$} & $\begin{array}{c}\text { Standar } \\
\text { dized } \\
\text { Coeffici } \\
\text { ents } \\
\end{array}$ & & & \multicolumn{2}{|c|}{$\begin{array}{c}\text { Collinearity } \\
\text { Statistics } \\
\end{array}$} \\
\hline & $\mathrm{B}$ & $\begin{array}{l}\text { Std. } \\
\text { Error }\end{array}$ & Beta & $\mathrm{T}$ & Sig. & $\begin{array}{c}\text { Tolera } \\
\text { nce }\end{array}$ & VIF \\
\hline 1 (Constant) & 3.630 & .120 & & 30.247 & .000 & & \\
\hline $\mathrm{BK}$ & .026 & .013 & .755 & 2.020 & .053 & .123 & 8.146 \\
\hline $\mathrm{BP}$ & -.001 & .014 & -.036 & -.096 & .924 & .123 & 8.146 \\
\hline
\end{tabular}

a. Dependent Variable: IPM 


\section{PENGARUH PENGELUARAN PEMERINTAH BIDANG KESEHATAN DAN PENGELUARAN PEMERINTAH BIDANG PENDIDIKAN TERHADAP INDEKS PEMBANGUNAN MANUSIA (IPM) DI PROVINSI SUMATERA

Berdasarkan tabel 2 diatas diperoleh nilai yaitu nilai Tolerance $0,123>0,10$ maka tidak terjadi multikolinearitas terhadap data yang di uji sedangkan nilai VIF 8,146< 10,00 maka tidak terjadi multikolinearitas. Dengan demikian dapat disimpulkan bahwa model pada penelitian ini memenuhi syarat untuk menjadi model regresi yang baik karena tidak terjadi korelasi antar variabel independen.

tabel 3

Hasil Uji Heteroskedastisitas

\begin{tabular}{|c|c|c|c|c|c|}
\hline \multirow[b]{2}{*}{ Model } & \multicolumn{2}{|c|}{$\begin{array}{c}\text { Unstandardized } \\
\text { Coefficients }\end{array}$} & \multirow{2}{*}{$\begin{array}{c}\text { Standardize } \\
\text { d } \\
\text { Coefficients } \\
\text { Beta }\end{array}$} & \multirow[b]{2}{*}{$\mathrm{t}$} & \multirow[b]{2}{*}{ Sig. } \\
\hline & $\mathrm{B}$ & Std. Error & & & \\
\hline $1 \quad$ (Constant) & .081 & .065 & & 1.241 & .225 \\
\hline BK & .003 & .007 & .252 & .472 & .641 \\
\hline BP & -.005 & .008 & -.355 & -.665 & .511 \\
\hline
\end{tabular}

a. Dependent Variable: ABS_RES

Berdasarkan tabel 3 diperoleh nilai signifikansi kedua variabel independen lebih dari 0,05. Dengan demikian dapat disimpulkan bahwa tidak terjadi masalah heteroskedastisitas pada model regresi.

Tabel 4

Hasil Uji Autokeorelasi

\begin{tabular}{|l|c|r|r|r|r|}
\hline Model & $\mathrm{R}$ & $\begin{array}{c}\mathrm{R} \\
\text { Square }\end{array}$ & $\begin{array}{c}\text { Adjusted R } \\
\text { Square }\end{array}$ & $\begin{array}{c}\text { Std. Error of } \\
\text { the Estimate }\end{array}$ & $\begin{array}{c}\text { Durbin- } \\
\text { Watson }\end{array}$ \\
\hline 1 & $.721^{\mathrm{a}}$ & .520 & .486 & .04810 & 1.845 \\
\hline
\end{tabular}

a. Predictors: (Constant), BP, BK

b. Dependent Variable: IPM

Berdasarkan tabel 4 nilai DW sebesar 1,845, nilai ini akan di bandingkan dengan nilai tabel menggunakan derajat kepercayaan 5\%, jumlah sampel 31 dan jumlah variabel bebas 2 , maka di peroleh nilai $\mathrm{d}_{\mathrm{L}}=1,297$ dan nilai $\mathrm{d}_{\mathrm{U}}=1,570$. Sehingga disimpulkan tidak ada autokorelasi pada data yang di uji. Hal ini dikarenakan nilai $4-1,845>1,570=(2,155>1,567)$. 


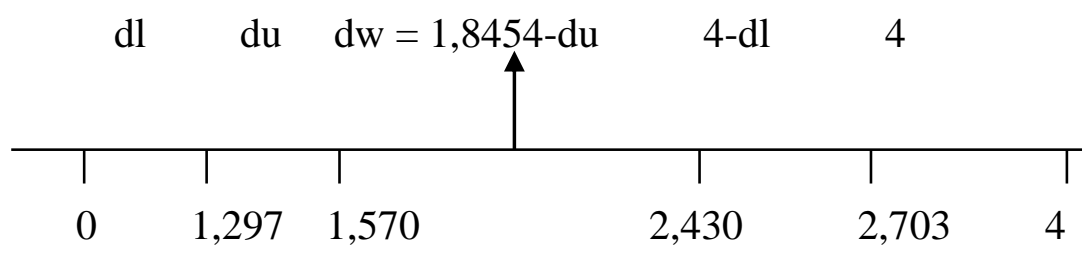

Untuk mengetahui pengaruh pengeluaran pemerintah bidang kesehatan dan pengeluaran pemerintah bidang pendidikan terhadap indeks pembangunan manusia di Provinsi Simatera Utara digunakan program SPSS (Statistical Product Solution Service) versi 23, dengan persamaan regresi yang terbentuk :

\section{Tabel 5}

Analisis Regresi Linier Berganda

\begin{tabular}{|c|c|c|c|c|c|}
\hline \multirow{2}{*}{\multicolumn{2}{|c|}{ Model }} & \multicolumn{2}{|c|}{$\begin{array}{c}\text { Unstandardized } \\
\text { Coefficients }\end{array}$} & \multirow{2}{*}{$\begin{array}{c}\text { Standardized } \\
\text { Coefficients } \\
\text { Beta }\end{array}$} & \multirow[b]{2}{*}{$\mathrm{T}$} \\
\hline & & B & $\begin{array}{l}\text { Std. } \\
\text { Error }\end{array}$ & & \\
\hline & (Constant) & 24,336 &, 119 & & 203,849 \\
\hline & $\mathrm{BK}$ & ,025 &, 013 & ,716 & 1,938 \\
\hline & BP & ,001 &, 014 & ,013 & ,036 \\
\hline
\end{tabular}

a. Dependent Variable: IPM

Berdasarkan hasil analisis di atas maka dapat dibuat model persamaan regresi yaitu:

$$
\begin{array}{ll}
\text { IPM } & =a+b 1 B K+b 2 B P \\
\text { IPM } & =24,336+0,025 \mathrm{BK}+0,001 \mathrm{BP}
\end{array}
$$

Untuk mengetahui seberapa besar pengaruh variabel independen terhadap variabel dependennya, dapat dilihat pada tabel berikut :

Tabel 6

Hasil Uji Determinasi $\mathbf{R}^{2}$

\begin{tabular}{|l|c|r|r|c|}
\hline Model & \multicolumn{1}{|c|}{$\mathrm{R}$} & $\begin{array}{c}\mathrm{R} \\
\text { Square }\end{array}$ & $\begin{array}{c}\text { Adjusted R } \\
\text { Square }\end{array}$ & $\begin{array}{c}\text { Std. Error of the } \\
\text { Estimate }\end{array}$ \\
\hline 1 & $.721^{\mathrm{a}}$ & .520 & .486 & .04810 \\
\hline
\end{tabular}

a. Predictors: (Constant), BP, BK

b. Dependent Variable: IPM

Berdasarkan tabel 6 di atas, besarnya hubungan antara pengeluaran pemerintah bidang kesehatan dan pengeluaran pemerintah bidang pendidikan secara simultan terhadap indeks 


\section{PENGARUH PENGELUARAN PEMERINTAH BIDANG KESEHATAN DAN PENGELUARAN PEMERINTAH BIDANG PENDIDIKAN TERHADAP INDEKS PEMBANGUNAN MANUSIA (IPM) DI PROVINSI SUMATERA

pembangunan manusia dengan nilai $\mathrm{R}$ sebesar 0,721 menunjukkan hubungan yang kuat. Sedangkan kontribusi secara bersama-sama dari pengeluaran pemerintah bidang kesehatan dan pengeluaran pemerintah bidang pendidikan dengan nilai $\mathrm{R}$ square adalah 52 persen sedangkan 48 persendi pengaruhi oleh variabel lain yang tidak dimasukkan dalam model penelitian ini. Dalam arti lain bahwa masih ada variabel independen lain yang mempengaruhi indeks pembangunan manusia di Sumatera Utara

\section{Pembuktian Hipotesis}

Uji hipotesis dalam penelitian ini terdiri dari uji T dan uji F.

Tabel 6

Hasil uji t

\begin{tabular}{|c|c|c|c|c|c|}
\hline \multirow[b]{2}{*}{ Model } & \multicolumn{2}{|c|}{$\begin{array}{c}\text { Unstandardized } \\
\text { Coefficients }\end{array}$} & \multirow{2}{*}{ 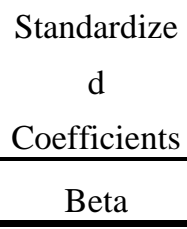 } & \multirow[b]{2}{*}{$\mathrm{t}$} & \multirow[b]{2}{*}{ Sig. } \\
\hline & B & Std. Error & & & \\
\hline (Constant) & 3.630 & .120 & & 30.247 & .000 \\
\hline BK & .026 & .013 & .755 & 2.020 & .053 \\
\hline BP & -.001 & .014 & -.036 & -.096 & .924 \\
\hline
\end{tabular}

a. Dependent Variable: IPM

Sebagai dasar pengambilan keputusan dapat digunakan kriteria pengujian sebagai berikut:

1. Apabila $-\mathrm{t}_{\text {tabel }}<\mathrm{t}_{\text {hitung }}<\mathrm{t}_{\text {tabel }}$ maka $\mathrm{H}_{0}$ diterima. Hal ini variabel independen secara individual tidak berpengaruh terhadap variabel dependen.

2. Apabilat ${ }_{h i t u n g}<-t_{\text {tabeldan }} t_{\text {hitung }}>\mathrm{t}_{\text {tabel }}$ maka $\mathrm{H}_{0}$ ditolak. Hal ini berarti variabel independen secara individual berpengaruh terhadap variabel dependen. Tingkat signifikan 0,05. Tabel distribusi t dicari dengan derajat kebebasan (df) n-k-1 atau 31-2-1=28 ( $\mathrm{n}$ adalah jumlah sampel dan $\mathrm{k}$ adalah jumlah variabel independen), maka diperoleh $t_{\text {tabel }}$ sebesar 1,701. Berdasarkan hasil uji signifikan parsial (uji t) diatas dapat dilihat bahwa pada variabel pengeluaran pemerintah bidang kesehatanmemilikit $_{\mathrm{h}}(2,020)>\mathrm{t}_{\mathrm{t}}(1,701)$ dimana $\mathrm{t}_{\mathrm{h}}(2,020)>$ th 1,701 maka 
$\mathrm{H}_{0}$ ditolak,artinya secara parsial ada pengaruhpengeluaran pemerintah bidang kesehatan terhadap indeks pembangunan manusia.

Pada variabel pengeluaran pemerintah bidang pendidikan memiiki thitung sebesar 0,096 dan $t_{\text {tabel }}$ sebesar 1,701 sehingga $-t_{t}(-1,701)<t_{h}(0,096)<t_{t}(1,701)$ sehingga $H_{0}$ diterima, artinya secara parsial tidak ada pengaruh signifikan pengeluaran pemerintah bidang pendidikan terhadap indeks pembangunan manusia..

Uji simultan atau uji $\mathrm{F}$ bertujuan untuk mengetahui pengaruh variabel independen secara bersama-sama berpengaruhkah atau tidak terhadap variabel dependennya dengan membandingkan antara nilai $\mathrm{F}$ hitung dan $\mathrm{F}$ tabel.

\section{Tabel 7 Hasil Uji F}

\begin{tabular}{|c|c|c|c|c|c|c|}
\hline \multicolumn{2}{|c|}{ Model } & $\begin{array}{l}\text { Sum of } \\
\text { Squares }\end{array}$ & Df & Mean Square & $\mathrm{F}$ & Sig. \\
\hline \multirow[t]{3}{*}{1} & Regression & .070 & 2 & .035 & 15.168 & $.000^{\mathrm{b}}$ \\
\hline & Residual & .065 & 28 & .002 & & \\
\hline & Total & .135 & 30 & & & \\
\hline
\end{tabular}
a. Dependent Variable: IPM
b. Predictors: (Constant), BP, BK

Dari tabel diatas dapat dilihat nilai $F_{\text {hitung }}$ yaitu 15,168 sedangkan nilai $F_{\text {tabel }}$ dapat diperoleh dengan menggunakan tabel $\mathrm{F}$ dengan derajat bebas (df) residual (sisa) yaitu 28 sebagai df penyebut dan df regression (perlakuan) yaitu 2 sebagai df pembilang dengan taraf signifikan 0,05, sehingga di peroleh nilai $F_{\text {tabel }}$ sebesar 3,340. Karena $F_{\text {hitung }}(15,168)>F_{\text {tabel }}$ $(3,340)$ maka $\mathrm{H}_{0}$ ditolak. Sehingga bunyi $\mathrm{H}_{a}$ adalah terdapat pengaruh pengeluaran pemerintah bidang kesehatan dan pengeluaran pemerintah bidang pendidikan terhadap Indeks Pembangunan Manusia di Provinsi Sumatera Utara secara simultan. 
PENGARUH PENGELUARAN PEMERINTAH BIDANG KESEHATAN DAN PENGELUARAN PEMERINTAH BIDANG PENDIDIKAN TERHADAP INDEKS PEMBANGUNAN MANUSIA (IPM) DI PROVINSI SUMATERA

UTARA

\section{KESIMPULAN}

Berdasarkan hasil analisis, maka pembahasan tentang hasil penelitian ini adalah sebagai berikut :

1. Pengaruh pengeluaran pemerintah bidang kesehatan (X1) terhadap indeks pembangunan manusia $(\mathrm{Y})$

Pegeluaran pemerintah bidang kesehatan merupakan salah satu kebutuhan masyarakat. Dari hasil hipotesis dengan melakukan uji-t diperoleh $t_{h}(2,020)>t_{t}$ $(1,701)$ dimana $t_{h}(2,020)>t_{h} 1,701$ maka $\mathrm{H}_{0}$ ditolak,artinya secara parsial ada pengaruh pengeluaran pemerintah bidang kesehatan terhadap indeks pembangunan manusia.

Sesuai dengan teori dalam buku Michael P. Todaro dengan judul Pembangunan Ekonomi Di Dunia Ketiga bahwa pengeluaran pemerintah bidang kesehatan memberikan kontribusi kepada indeks pembangunan manusia yaitu modal manusia. Modal manusia disini merupakan hasil dari investasi yang diberikan pemerintah untuk kesehatan dimana modal kesehatan yang baik dapat meningkatkan pembangunan manusia yang baik. Hasil penelitian ini juga sejalan dengan hasil penelitian yang dikemukakan oleh Sugiarto A.Santoso,Abu Bakar Hamzah, Mohd Nur Syechalad yang berjudul Analisis Pengaruh Pengeluaran Pemerintah Kabupaten/Kota Sektor Kesehatan dan Sektor Pendidikan Terhadap Indeks Pembangunan Manusia di Provinsi Aceh. Menyatakan "pengeluaran pemerintah sektor kesehatan berpengaruh signifikan terhadap indeks pembangunan manusia di Provinsi Aceh".

Jadi kesimpulannya pengeluaran pemerintah bidang kesehatan berpengaruh terhadap indeks pembangunan manusia di Provinsi Sumatera Utara. 
Pengeluaran pemerintah bidang kesehatan didukung oleh peningkatan investasi kesehatan diantaranya adalah kehadiran anak-anak disekolah dimana anak-anak yang sehat akan lebih berprestasi dan akan meningkat indeks pembangunan manusia.

2. Pengaruh pengeluaran pemerintah bidang pendidikan(X2) Terhadap indeks pembangunan manusia(Y)

Pengeluaran pemerintah bidang pendidikan merupakan suatu bentuk investasi sumber daya manusia, pendidikan merupakan salah satu komponen utama dalam kebutuhan masyarakat. Pada variabel pengeluaran pemerintah bidang pendidikan memiliki thitung sebesar 0,096 dan $t_{\text {tabel }}$ sebesar 1,701 sehingga $-t_{t}(-, 701)<t_{h}(0,096)<t_{t}(1,701)$ sehingga $H_{0}$ diterima, artinya secara parsial tidak ada pengaruh signifikan pengeluaran pemerintah bidang pendidikan terhadap indeks pembangunan manusia.

Hasil penelitian ini bertentangan dengan buku Michael P. Todaro dengan judul Pembangunan Ekonomi Di Dunia Ketiga yang menyatakan bahwa pengeluaran pemerintah bidang pendidikan memberikan kontribusi kepada indeks pembangunan manusia yaitu modal manusia. Modal disini merupakan hasil dari investasi yang diberikan pemerintah untuk pendidikan dimana modal pendidikan yang baik akan meningkatkan pembangunan manusia yang baik. Penelitian inisejalan dengan penelitian yang dikemukakan oleh Astri Winarti yang berjudul Analisis Pengaruh Pengeluaran Pemerintah Bidang Pendidikan, Kemiskinan, Dan PDRB Terhadap Indeks Pembangunan Manusia Di Indonesia Periode 1992-2012. Penelitian Astri Winarti menyatakan "bahwa variabel pengeluaran peemrintah bidang pendidikan berpengaruh negatif dan tidak signifikan terhadap indeks pembangunan manusia" 


\section{PENGARUH PENGELUARAN PEMERINTAH BIDANG KESEHATAN DAN PENGELUARAN PEMERINTAH BIDANG PENDIDIKAN TERHADAP INDEKS PEMBANGUNAN MANUSIA (IPM) DI PROVINSI SUMATERA

Jadi kesimpulannya pengeluaran pemerintah bidang pendidikan tidak berpengaruh terhadap indeks pembangunan manusia. Sesuai dengan UndangUndang Dasar 1945 menyebutkan tentang mencerdaskan kehidupan bangsa yang dikaitkan dengan pendidikan. Seberapa besar komitmen pemerintah terhadap pembangunan pendidikan antara lain tercermin dari anggaran yang disediakan dalam APBN. Pengeluaran pemerintah bidang pendidikan tertuang dalam UU No 20 tahun 2003 yang menyebutkan bahwa "dana pendidikan selain gaji pendidik dan biaya pendidikan kedinasan dialkokasikan minimal 20 persen dari Anggaran Pendapatan dan Belanja Nasional (APBN) pada sektor pendidikan dan minimal 20 persen dari APBD”.

3. Pengaruh pengeluaran pemerintah bidang kesehatan(X1) dan pengeluaran pemerintah bidang pendidikan (X2) secara bersama-sama terhadap indeks pembangunan manusia (Y).

Dari tabel diatas dapat dilihat nilai $F_{\text {hitung }}$ yaitu 15,168 sedangkan nilai $F_{\text {tabel }}$ dapat diperoleh dengan menggunakan tabel $\mathrm{F}$ dengan derajat bebas (df) residual (sisa) yaitu 28 sebagai df penyebut dan df regression (perlakuan) yaitu 2 sebagai df pembilang dengan taraf signifikan 0,05 sehingga di peroleh nilai $F_{\text {tabel }}$ sebesar 3,340. Karena $F_{\text {hitung }}(15,168)>F_{\text {tabel }}$ $(3,340)$ maka $\mathrm{H}_{0}$ ditolak. Sehingga bunyi $\mathrm{H}_{\mathrm{a}}$ adalah terdapat pengaruh pengeluaran pemerintah bidang kesehatan dan pengeluaran pemerintah bidang pendidikan terhadap indeks pembangunan manusia di Provinsi Sumatera Utara secara simultan. Sesuai dengan teori yang dikemukakan Michael P. Todaro dengan judul Pembangunan Ekonomi Di Dunia Ketiga yang menyatakan bahwa keterkaitan antara kesehatan dan pendidikan mencakup perlakuan analitis yang serupa, karena keduanya merupakan bentuk dari modal manusia dampak ganda dari pengeluaran untuk kesehatan terhadap efektifitas sistem pendidikan. Dan penelitian ini sejalan 
dengan yang dikemukakan oleh Schultz dalam buku Ekonomi Pembangunan dan Perencanaan yang menyatakan bahwa pengembangan sumber daya manusia (modal manusia) diikuti oleh fasilitas pelayanan kesehatan serta pendidikan yang diorganisasikan secara formal pada tingkat dasar, menengah, dan tinggi.

\section{DAFTAR PUSTAKA}

Adi Widodo, Wadirin dan Johanna Maria K, “ Analisis Pengaruh Pengeluaran Pemerintah Sektor Pendidikan dan Kesehatan Terhadap Pengentasan Kemiskinan Melalui Peningkatan Pembangunan Manusia di Provinsi Jawa Tengah ”, dalam Jurnal Ekonomi Pembangunan, Volume 1, No. 1, Juli 2011.

Adiwarman Azwar Karim, Sejarah Pemikiran Ekonomi Islam Edisi Ketiga, Jakarta: PT RajaGrafindo Persada, 2012.

Badan Pusat Statistik, Publikasi UNDP dalam Human Development Report (HDR) tahun 1995, Medan: BPS, 1995.

Departemen Agama RI, Alquran dan Terjemahan, Jakarta: Bintang Indonesia,2011.

M. Quraish Shihab, Tafsir Al- Mishab, Pesan dan Keserasian Al- Qur'an Volume 9, Jakarta: Lentera Hati, 2002.

Michael P. Todaro, Pembangunan Ekonomi Di DuniaKetiga, Jakarta: Erlangga, 2003.

Mudrajad Kuncoro, Masalah Kebijakan Dan Politik Ekonomi Pembangunan, Jakarta: Erlangga, 2010.

Muhammad Nasib, Kemudahan dari Allah Ringkasan Tafsir Ibnu Katsir Jilid 1,Jakarta: Gema Insani Press, 1999.

Mujtahid, Reformasi Pendidikan Islam, Malang: UIN-Malang Press, 2011.

Nurul Izzah, “Analisis Pengaruh Indeks Pembangunan Manusia dan Inflasi Terhadap Pertumbuhan Ekonomi di Provinsi Riau," dalam Jurnal Ekonomi, Volume 1, No. 2, Juli- Desember 2015.

Rozalinda, Ekonomi Islam Teori dan Aplikasinya Pada Aktivitas Ekonomi , Jakarta: Rajawali Pers, 2015. 


\section{PENGARUH PENGELUARAN PEMERINTAH BIDANG KESEHATAN DAN PENGELUARAN PEMERINTAH BIDANG PENDIDIKAN TERHADAP INDEKS PEMBANGUNAN MANUSIA (IPM) DI PROVINSI SUMATERA

Rusli Yusuf, Pendidikan dan Investasi Sosial, Bandung: Alfabeta,2011.

S. Margono, Metodologi Penelitian Pendidikan, Jakarta: Rineka Cipta, 2000.

Sadono Sukirno, Ekonomi Pembangunan: Proses Masalah dan Dasar Kebijakan Edisi Kedua, Jakarta: Kencana, 2006.

Setiawan dan Kusrini, Endah, Dwi. 2010. Ekonometrika, Yogyakarta : Andi.

Sudarwan Danim, Ekonomi Sumber Daya Manusia Analisis Ekonomi Pendidikan, Isu-Isu Ketenagakerjaan Pembiyaan Investasi, Ekuilitas Pendidikan, dan Industri Pengetahuaan, Bandung: CV Pustaka Setia, 2003.

Sugiono dan Susanto, Agus. 2015. Cara Mudah Belajar SPSS dan Lisrel Teori Dan Aplikasi Untuk Analisis Data Penelitian, Bandung : Alfabeta.

T. Gilarso, Pengantar Ilmu Ekonomi Makro, Yogyakarta: Kanisius, 2004. 